\title{
The effects of electrical voltage differences and initial fragment size on growth performance and survival rate of coral acropora cerealis in biorock method
}

\begin{abstract}
Biorock is one of transplantation method which succesfull in coral reef restoration activities. The result of any research in several countries has been proven that biorock technology is capable to accelerate growth and increases the survival rate of coral reef ecosystem in extreme environmental conditions. The objective of this research out the effects of electrical voltage difference and initial fragment size in biorock transplantation method toward coral growth and survival rate. The materials observed in this study were fragments of coral Acropora cerealis in Pemuteran Beach, Bali. The study was conducted by using field experiment method and the coral transplantation method were carried out by using biorock technology. The main parameters were the growth and survival rate of the coral. Supporting data in this study were water physical and chemical parameters, including: temperature, salinity, $\mathrm{pH}$, mineral sedimentation, and brightness. In addition, the highest growth and survival rate could be seen in 6 volt biorock method on both fragment sizes.
\end{abstract}

Keywords: Biorock, Coral transplantation, Acropora cerealis, Voltage, Initial size, Growth performance, Survival rate
Volume 4 Issue 4 - 2016

\author{
Dias Natasasmita, Diah Permata Wijayanti, \\ Chrisna Adhi Suryono \\ Department of Marine Science Diponegoro University, \\ Indonesia
}

Correspondence: Dias Natasasmita, Department of Marine Science Diponegoro Univesity, Semarang, Indonesia, Tel +628I341243387, Email diasnatasamita@ymail.com

Received: May 16, 2015 | Published: August 10,2016

\section{Introduction}

Biorock technology is a process of mineral electro deposit in the sea water, usually called as mineral accretion technology. This technology is developed by Professor Hilbertz WH, ${ }^{1}$ a marine scientist in 1974. Biorock has structure created from iron and directly flown by very low electrical charges to grow and repair marine structures at any scale and to rapidly grow or restore vibrant marine ecosystems. The chemical mechanism occurs when electrical current causes electrolysis reaction which produces natural building material in the sea water, such as calcium carbonate and magnesium hydroxide. At the same time, this electro-chemistry process will accelerate the growth of organism around the biorock structure. Therefore, the coral reef which transplanted on the iron structure will grow faster. ${ }^{2}$

Electrical technology used in the biorock method is DC current with approximately between 1-12 volt. The magnitude depends on the energy source. This electrical power has great impact on the high growth and diamater of coral. ${ }^{3}$ The coral in biorock structure can grow until 2-6 times faster than the natural coral. The coral growing with biorock assistance has restoration ability from physical damage until 20 times faster than the coral growing naturally. ${ }^{2}$ The first experiment in discovery Bay, Jamaica transplanted small fragments and fingers coral, Poritesporites, which tripled in size in three mounts. Subsequent experiments with staghora coral, Acropora cervicornis, showed growth rate of about $8 \mathrm{~cm}$ in 10 weeks, or rates arround five times higher that had ever been recorded in this species. The growth of corals on biorock in Maldives showed 16-50 times higher survival after severe high-temperature bleaching events in $1998 .{ }^{1}$ During severe in the gulf of Thailand in 2010, biorock corals had markedly lower bleaching, faster recovery and higher survival than corals on sorrounding reefs. The same result has been repeatedly noticed during mild bleaching events in Bali and Lombok, Indonesia. ${ }^{4}$
Unfortunately, not all of biorock experiments was successful. The data analysis by Beddoe et al. ${ }^{5}$ fitted a single curve to the entire data set and failed distinguish the importance of the separate period with the power off. They have fitted each segment separately. No residual effect biorock methods and have inevitably led to inferior result. These people who were not trained in biorock methods, used conditions that were far suboptimal and they blames their failure on the technology, not on their lack of mastery of it. ${ }^{6}$

Almost of them grossly overcharged in order to get the fast result. In one case, in which authors actually claimed that electrical fields reduced the coral growth rates in total contradiction to all the results, the authors deliberately concealed what they knew, namely that the apparent lower growth rate of one species coral was due to the fact that every single growth tip had been systematically bitten off as a breeding territorial marker by territorial terminal male parrotfish. They set up the experiment for them and personally saw the freshly broken fragments lying all over the bottom around it.

In addition, another method has been proposed that electric current be applied to the wire which the fragments are attached for promoting deposition (mineralization) of the carbon ion and calcium ion contained in the seawater to facilitate the growth of the corals. Although there are some positive results in abroad, ${ }^{8}$ this experiment did not show outstanding results in Okinawa.

Overall, the determination of voltages level is still in the experimental stage and it is often caused overcharged effect which made the coral growing faster but losing their hardness. In addition, transplantation method by using big colonies of coral as transplants are highly risk to destroy the ecosystem. Then, it is important to do some experiment with lower or higher electrical voltage differences and variations of initial fragment size of coral to find out the most effective numbers and interaction between the both of voltage level and fragment size to 
accelerate growth performance and increases the survival rate of coral (Acropora cerealis) in biorock method.

\section{Material and methods}

The materials observed in this experiment were the fragments of coral Acropora cerealis(A. cerealis, Veron ${ }^{9}$ located in pemuteran beach, gerokgak village, buleleng district, bali, where is exactly at the coordinate of $114^{\circ} 40^{\prime} 27.3^{\prime \prime} \mathrm{E}-114^{\circ} 39^{\prime} 18.9^{\prime \prime} \mathrm{E}$ dan $08^{\circ} 07^{\prime} 5.7^{\prime \prime} \mathrm{S}$ $08^{\circ} 07^{\prime} 33.4$ ' S.

The instruments used in this experiment were: SCUBA diving, biorock structure instalations, calipers, underwater camera, board, stationery, litmus paper, sechii disk, thermometer and ocean current instrument. The main parameters measured were the coral growth performance (height) and survival rate. The supporting parameters are physics and chemical parameters of sea waters, including: temperature, salinity, $\mathrm{pH}$, sedimentation and brightness.

\section{Experimental design}

The research was conducted by usingfield experiment method, i.e. a procedure to find out causal-effect relationship by giving one or more treatments and comparing the results to observe the effects on the research object in the field. ${ }^{10}$ The experiment was performed in reef seen aquatics, pemuteran beach, bali, at 8-10 meters depth, for 12 weeks in january until march 2014. The experimental design used was a split plot experimental design which had two factors, they were voltage differences as the major plot factor in three different levels ( 0 volt, 6 volt and 12 volt) and the initial size of coralfragment as a minor plot factor in two different sizes $(3 \mathrm{~cm}$ and $5 \mathrm{~cm})$. The total of fragments transplanted were 30 fragments which put randomly on the three biorock structures and each of biorock structure was flown by different electrical voltage and contained 10 coral fragments in two initial size variations.

The treatments were conducted in this research is:

i. 10 coral transplant ( 5 fragments in $3 \mathrm{~cm}$ size and 5 fragments in 5 $\mathrm{cm})$ was stimulated by $6 \mathrm{v}$ voltage.

ii. 10 coral transplant ( 5 fragments in $3 \mathrm{~cm}$ size and 5 fragments in 5 $\mathrm{cm}$ ) was stimulated by $12 \mathrm{v}$ voltage.

iii. 10 coral transplant ( 5 fragments in $3 \mathrm{~cm}$ size and 5 fragments in 5 $\mathrm{cm})$ without any treatments.

\section{Preparation of biorock structure and coral transplant}

The square iron transplantation tables with dimension $1 \times 1 \times 0.5$ meters (lenght, width and height) were used in this experiment as biorock structure. There were three biorock structure with the respective electrical voltage of 0 volt (control), 6 volt, and 12 volt. Each biorock structure was installed with two paths of cable which connected to a power supply as the source of DC electrical current. One cable was connected to iron structure as the cathode (negative pole) andthe another one was connected to anode (positif pole) which was made from titanium with the dimensions of $1 \times 1$ meter and framed by pipes which filled by sands. The anode was placed not too far from the iron structure in the depth of sea water, and the length of the cable used was adjusted to the expected distance, the depth of transplant location and the slope condition on the beach. A major colony of coral Acropora cerealisas the donor corals was gained in the depth of 2-3 meters. The sample of the major colony has diameter about $20 \mathrm{~cm}$ in length and it is free from any disease Glynn et al. ${ }^{11}$ states that the main colony should be free from any disease and did not face any bleaching.
All samples of coral transplant were placed horizontally and strongly tied by using ties cables along the intersection between vertical and horizontal line of the iron. The distance among coral transplant to each otherwas made in the same size $(0.25$ meter) and managed in good position so it would nottouched and affected each other. The samples of coral fragmentswas placed randomly in the biorock structure. It was aimed that each sample had the same opportunity to receive the treatment. ${ }^{12}$

\section{Data collection}

The data were collected from the result of weekly observation from the research object. The collected data were the data of fragments growth $(\mathrm{cm})$, photos of coral fragments, the total of living coral in the end of reserach, mineral sample and water quality parameters. The growth performance of coral was evaluated in terms height. The survival rate of coral was calculated as difference between the numbers of living fragments stocked at the beginning and survived at the end of the experiment. The measurment of coral fragments was performed using the result of coral fragments photo collection and processed using CPCe software (Coral Point Count with Excel extension) to get more accurate data ofheight andgrowth performance of coral fragments.

\section{Data processing}

The data calculation process was performed by using descriptif method. The data of coral growth was determined using the formula by Kudus \& Wijaya, ${ }^{13}$ the growth performance was determined using the formula by Effendie ${ }^{14}$ and the survival rate was determined using the formula by Ricker. ${ }^{15}$

Coral growth formula

$$
\beta=L_{t}-L_{0}
$$

Where :

$\beta=$ Coral Growth $(\mathrm{cm})$

$L_{t}=$ Height of coral at weekly observation $(\mathrm{cm})$

$L_{o}=$ Height of coral at the beginning of research $(\mathrm{cm})$

Coral growth performance formula

$$
P=\frac{L_{t}-L_{0}}{t}
$$

Where :

$P=$ Coral Growth Performance (cm/week)

$L_{t}=$ Average (Height of coral) at the end of research $(\mathrm{cm})$

$L_{0}=$ Average (Height of coral) at the beginning of research $(\mathrm{cm})$

$t=$ Total Observation Time (week)

Survival rate formula

Where :

$S R=$ Survival Rate $(\%)$

$N_{t}=$ Total living coral at the end of research

$N_{0}=$ Total living coral at the beginning of research

In addition, Scanning Electron Microscope Test (SEM) and Energy Dispersive Ray Analysis (EDX) were conducted to analyze the mineral builded on the cathode. This analysis aims to find out the influence of voltage levelto mineral deposits which has builded on 
biorock structure. The results of SEM and EDX were showed by data of topography, morphology and mineral composition which could be analyzed both quantitatively and qualitatively. So, it could be specifically showed the advantages and disadvantages of electrical voltages differences treatmenton the mineral building processwhich could be accelerated the growth performance of coral fragments.

\section{Statistical analysis}

Statistical analysis was performed using SPSS 16. Analysis of repeated measurement ANOVA was used to determine the effect of electrical voltage differences and initial fragment size on growth performance and survival rate of coral. When, appropriate, the Turkey's HSD (Honestly Significant Differences) post-hoc test was employed to check for differences between means. The 5\% significance level was applied for all tests.

\section{Results}

The observation results in this experiment include growth performance, survival rate, and mineral composition and waters quality parameters.

\section{Growth performance}

The complete data of growth rate of coral Acropora cerealis in 12 weeks are presented in (figure 1) the average results of coral growth performance which cultivated by using 6 volt biorock method is $(3.74$ $\pm 0.16 \mathrm{~cm})$ in $3 \mathrm{~cm}$ fragment size and $(6.02 \pm 0.63 \mathrm{~cm})$ in $5 \mathrm{~cm}$ fragment size. In the 12 volt biorock method, the average result of the coral growth performance is $(4.55 \pm 0.40 \mathrm{~cm})$ in $3 \mathrm{~cm}$ fragment size and $(6.13 \pm 0.39 \mathrm{~cm})$ in $5 \mathrm{~cm}$ fragment size. While, in non-biorock method
$(0$ volt), the average results of growth performance is $(3.31 \pm 0.09$ $\mathrm{cm})$ in $3 \mathrm{~cm}$ fragment size and $(5.21 \pm 0.05 \mathrm{~cm})$ in $3 \mathrm{~cm}$ fragment size.
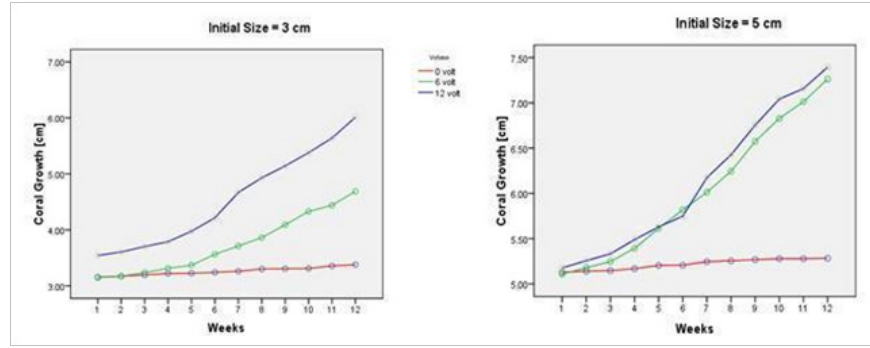

Figure I Chart of growth performance of coral Acropora cerealis in electrical voltage differences and initial size variations.

Based on this result, it could be seen that biorock and initial fragment size treatment has given different effects on the growth performance ofcoral transplant. This result is also supported by statistical analysis calculation by using repeated measurement ANOVA which showed that biorock treatment with difference of higher voltage (12 volt) and lower voltage ( 6 volt) as well as the difference of higher size $(5 \mathrm{~cm})$ and lower size $(3 \mathrm{~cm})$ have real different effects $(\mathrm{F}$ count $>\mathrm{F}$ Table) toward the growth of coral on non-biorock method ( 0 volt). Although, the 6 volt biorock treatment did not show significantly different results with 12 volt biorock treatment in both of initialsize treatment. But, this both Biorock treatment has showed that it could be accelerated the growth performance of coral in short time. The results of variance analysis showed the effects of electrical voltage differences and fragment size variationson coral growth performance can be seen in table 1 .

Table I The results of variance analysis about the effects of different electrical voltage differences and fragment size variations on coral growth performance

\begin{tabular}{lllllll}
\hline & df & jk & kt & F-calculate & F-Table I & F-Table 2 \\
\hline Variance Source & & & & & $5 \%$ & I\% \\
Week & II & 15 & 1.36 & & & 4.44 \\
Voltage (A) & 3 & 19.9 & 6.63 & $22.50 * *$ & 3.28 & 7.25 \\
Variance Error(a) & 33 & 9.7 & 0.29 & & & 4.26 \\
Size (B) & 1 & 87.67 & 87.67 & $21.7 I^{* *}$ & 4.06 & \\
A x B & 3 & 1.49 & 0.5 & $11.93 * *$ & 2.82 & \\
Variance Error (b) & 44 & 1.83 & 0.04 & & & \\
General & 95 & 134.1 & & & & \\
\hline
\end{tabular}

Where: df: Degree of Freedom; jk: Sum of Square; kt: Mean Square.

The comparison of two methods was showed that the biorock method treatment has better effects than the normal one which did not use electrical current. The biorock method treatment in 6 volt and 12 volt have showed a greatly accelerates coral growth than the non-biorock method. Shuhmacher ${ }^{8}$ states that in the same environment, biorock method is able to give a lot of positive effects on coral's weight and height increases. The first biorock experiment was performed in discovery bay, Jamaica in 1980, even shows great results. Only in 10 weeks, the coral from Acropora cervicornis species grew up to $8 \mathrm{~cm} .{ }^{1}$

According to Hilbertz \& Goreau, ${ }^{1}$ the growth performance of the coral transplanted by using electrolysis technique is faster than the normal growth. Electrolysis technology has improved mineral ions concentration, such as $\mathrm{Ca} 2+, \mathrm{Mg} 2+, \mathrm{CO} 32-, \mathrm{OH}-$, and $\mathrm{HCO} 3-$. So, the transplanted coralon biorock cathode will exposed by abundant of mineral ions. This electrochemistry process will enrich the $\mathrm{Ca} 2+$, $\mathrm{CO} 32-$, and $\mathrm{HCO} 3-$ ions that can give positive effects toward the calcification and growth performance. ${ }^{16}$

\section{Survival rate}

Based on the results of weekly observation for 3 months, there was 24 fragments of coral Acropora cerealiswhich has survived until the end of the research. In non-biorock method, there were 3 coral fragments died cause of bleaching and 2 coral fragments were covered with algae. While, in biorock method there was one coral fragment died cause of bleaching. The percentage of coral survival rate in each treatment could be seen in table 2 . As a result of comparison between the non-biorock fragment and the biorock fragment that were transplanted in two different voltages, those biorock fragments showed higher survival rate for all fragments size. For the fragments that were used biorock method, $80-100 \%$ of the all size was survived, but in non-biorock method showed lower survival rate and died one after the other during the observations. The $5 \mathrm{~cm}$ fragments in non-biorock method showed the lowest survival rate about $40 \%$. According to Goreau, ${ }^{4}$ the coral were transplanted in biorock method has ability to self restoration from physical damage until 20 times faster than natural 
growing coral. Besides, the coral in biorock has also survival level of 50 times higher than the increase of the temperature causing bleaching phenomenon. The biorock experiment done in Maladewa shows the survival rate of 16-50 times better after bleaching due to temperature increase in 1998. ${ }^{1}$ Even in the condition of substrate which does not support, such as muddy substrate in panama, republic of dominica and thailand, the biorock experiment for some porites species and soft coral can grow significantly. ${ }^{3}$ It was supported by the statement of Kimberley ${ }^{17}$ proposing that biorock method can make higher survival rate of coral toward the environment. Electrical current given to coral was indicated playing important role toward restoration stimulation of membrane, cell regeneration and damaged tissue restoration. These make the coral in biorock method can grow with the very high survival rate toward stress and environmental change. ${ }^{18}$

Table 2 The survival rate of coral transplant indifferent voltage and initial size

\begin{tabular}{llll}
\hline \multicolumn{3}{c}{ Voltage } \\
\hline Initial Size & 0 volt & 6 volt & 12 volt \\
$3 \mathrm{~cm}$ & $60 \%$ & $100 \%$ & $100 \%$ \\
$5 \mathrm{~cm}$ & $40 \%$ & $100 \%$ & $80 \%$ \\
\hline
\end{tabular}

\section{Mineral composition}

The results of growth performance was supported by the results of photomicrograph by using SEM and EDX Analysis, it has showed the differently topography and morphology between mineral sample which builded on the 6 volt and 12 volt biorock cathode. The photomicrograph of mineral structure on 6 volt biorock cathode is looks brighter than mineral structure on 12 volt biorock cathode for each resolution (Figure 2). It is mean that the mineral structure on 6 volt biorock cathode has better hardness level, atom structure and molecule weight than the mineral structure on 12 volt biorock cathode. Yurugi et al. ${ }^{19}$ proposes that the analysis results of SEM and EDX from the atom whose high molecule weight and solidity level shall brighter color than that whose lower molecule and solidity level. For more details, SEM and EDX analysis results showed that the sample of mineral in 6 volt biorock cathode is contained some elements, i.e. carbon (7.48\%), Oxide (61.94\%), natrium (3.64\%), magnesium (26.24\%), sulphur $(0.23 \%)$, and calcium $(0.57 \%)$. Meanwhile, in the sample of mineral in 12 volt biorock cathode is contained the elements of Carbon (12.09 $\%)$, Oxide $(59.92 \%)$, natrium $(2.29 \%)$, magnesium $(24.80 \%)$, sulphur $(0.33 \%)$, and calcium $(0.37 \%)$ (Figures $3 \& 4)$. From Figures 3 $\& 4$, we could seen that the calcium $(0.57 \%)$ and magnesium $(26.24$ $\%$ ) elements composition on 6 volt biorock cathode is higher than calcium $(0.37 \%)$ and magnesium $(24.80 \%)$ elements composition on 12 volt biorock cathode. It is showed that the growth performance of coral is in line with the mineral deposits which influenced this process. In line with this result, Goreau ${ }^{4}$ states that the electrolysis reaction that occurs as a result of the electrical current to anode and cathode will produce natural mineral ions in the sea water, such as calcium carbonate and magnesium hydroxide. Calcium and magnesium which be the most important elements in the coral growth will be deposited around the biorock cathode. If there are abundant elements of calcium and magnesium around the cathode, the coral seed which transplanted in the cathode will grow faster.

\section{Water quality parameters}

When monitoring coral transplant, it is important to monitor their habitat environment at the same time to understand it as one of several factors affecting coral survival. The important environmental factors that can affect the growth performance and survival rate of coral are temperature, water movement, sedimentation and predators.
By monitoring water quality continuously for long term, it is possible to discover water quality trends in locations that effect growth and survival of the coral. The coral transplantation site was located in pemuteran beach, North Bali, Bali Island. Because of the indented coast line, the current is relatively slow and the amount of sedimentation is relatively high. But, the waters quality in the observation area wash owed general condition of chemical and physics parameters in the sea waters. The results of this parameter measurement showed that the observation area has supported and ideal condition for the growth and survival rate of coral in the temperature of $29^{\circ} \mathrm{C}$, $\mathrm{pH}$ value of 8-9, salinity of about $35 \mathrm{ppt}, 2-20 \mathrm{~cm} / \mathrm{s}$ current speed, depth of 8 meter and brightness is about 6-7 meter. Based on the data and result from the previous research, it could be seen that there are so many variation of growth performance and survival rate in different place for this biorock technology application. It means that there is an environmental role on how this biorock technology working. Currently, it couldn't be sure how far this environmental factors influence the biorock performance, because we have to do more specific experiment which involve the water quality parameter differences to see the result. These effects of water quality and environmental parameters are still interest to researched and discussed.
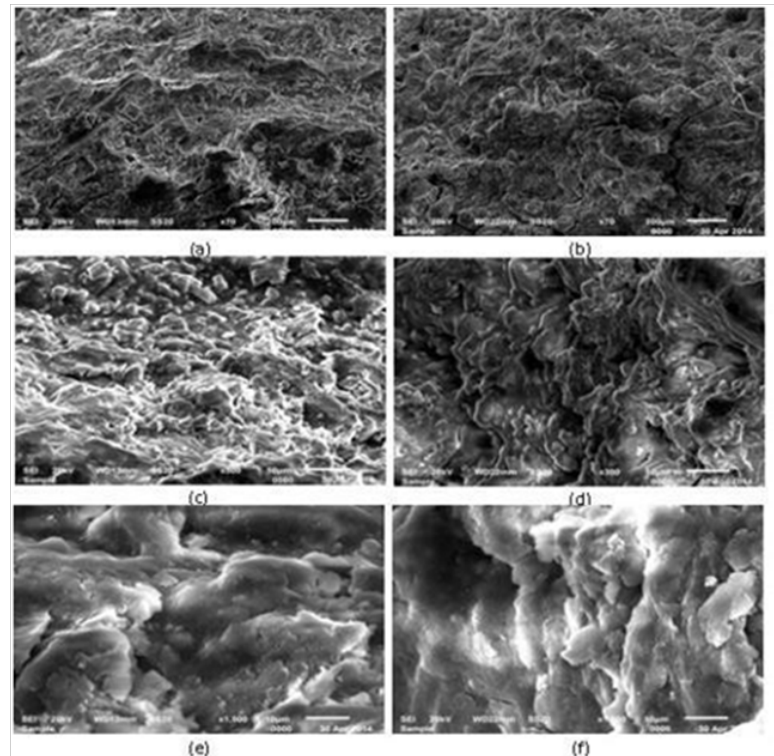

Figure 2 The SEM and EDXAnalysis Results (a) 6 volt; 70x, (b) 12 volt; 70x, (c) 6 volt; 300x, (d) 12 volt; 300x, (e) 6 volt; 1500x, (f) 12 volt; 1500x.

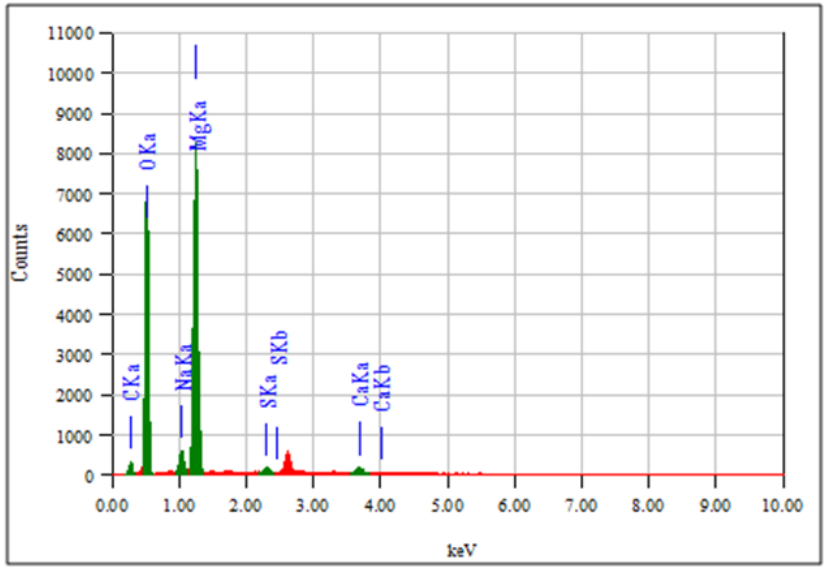

Figure 3 Chart of SEM and EDX Analysis Results (Mineral Composition in 6 volt Biorock Cathode). 


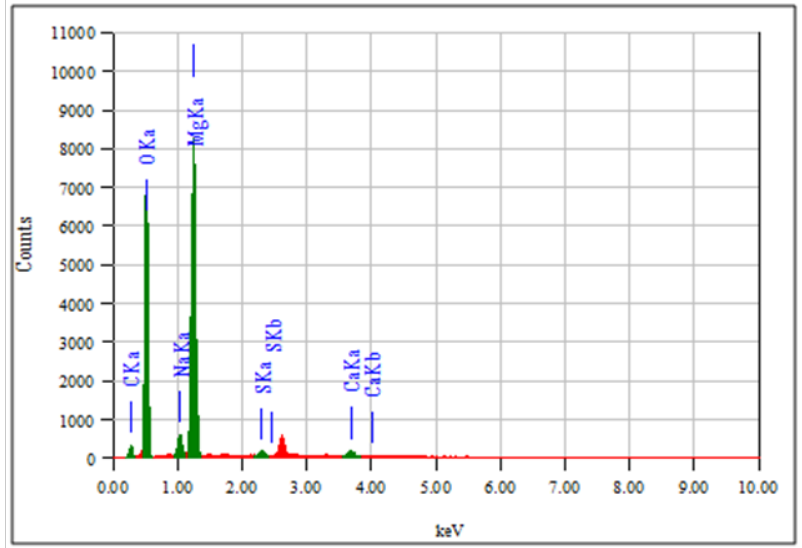

Figure 4 SEM and EDX Analysis Results (Mineral Composition in 12 volt Biorock Cathode).

\section{Conclusion}

Based on the 12 weeks research results from January-March 2014in pemuteran beach, Bali, it could be concluded that the electrical voltage differences (volt) and the initial fragments size (height) in the biorock method have significantly different effects $(\mathrm{P} \leq 0.05)$ on coral growth than the non-biorock method. Although, the statistical analysis results showed in different and real correlation $(P \geq 0.05)$, the electrical treatment in 6 volt biorock method showed a better growth than the 12 voltbiorock method. Italso could be seen from the different quality of calcium deposit and mineral compositionwhich builded around the biorock cathode. The structure and composition of calcium deposit which buildedon 6 volt biorock cathode was higher than the one built on 12 voltbiorock cathode. Overall, the average survival rate of coral transplant was $80 \%$. The highest survival rate $(100 \%)$ was showed in 6 volt biorock method for the all size. Then, the most effective and efficient transplantation by using biorock method was biorock instalation with6 volt level and the initial fragments size between 3 and $5 \mathrm{~cm}$.

\section{Acknowledgments}

None.

\section{Conflicts of interest}

None.

\section{References}

1. http://www.google.co.in/patents/US5543034

2. Goreau TJ. Biorock as a technical adaptation strategy for coral reef protection and restoration in the tourism industry. Global Coral Reef Alliance, USA. 2009.
3. Robbe D. Gili Biorock Project-Situation. Gili Eco Trust, Indonesia. 2010 .

4. Goreau T. Practical reef restoration. 2006.

5. Beddoe L, Agard J, Philip DT. Electrical enhancement of coral growth in Tobago. Proceedings of the 11th International Coral Reef Symposium, USA. 2008.

6. Shuhmacher $\mathrm{H}$, Use artificial reefs with special reference to the rehabilitation of coral reefs. Booner Zoologische Monograpien. 2002;50:81-108.

7. Borell EM, Romatzki SBC, Ferse SCA. Differential physiological responses of two congeneric scleractinian corals to mineral accretion and an electric field Coral Reef. 2010;29(1):191-200.

8. Shuhmacher H, Treek P, Eisinger M, et al. Transplantation of coral fregments from ship groundings on elecreochemically formed reef structures. Coral Reef Sym, Panama. 2000.

9. Veron JEN. Coral of Australia and the Indo-Pacific. Angus \& Robertos, Australia. 1993.

10. Moh Nazir. Metode Penelitian. Ghalia, Indonesia. 1998.

11. Glynn E, Richard Dodge E, Daniel PT, et al. Growth and Survivorship of Scleractinian Coral Transplants and The Effectiveness of Plugging Core Holes in Transplant Donor Colonies. Proceedings of 10th International Coral Reef Symposium. 2006;8:1657-1664.

12. Edwards AJ, Gomez ED. Reef Restoration Concepts and Guidelines: Making Sensible Management Choices In The face of uncertainty, Indonesia. 2008.

13. Kudus A, Dan I, Wijaya. Transplantasi Biota Karang. Laporan ke-1. Program Penelitian. IPB. Bogor.133 Hal. 2001.

14. Effendie MI. Metode Biologi Perikanan. (1st edn), Yayasan Dewi Sri, Bogor, Indonesia. 1979.

15. Ricker, Bill. Handbook of computations for biological statistics of fish populations. Bull, Fish Res Board Can. 1975;119:300.

16. Sabater MG, Yap HT. Long-term effects of induced mineral accretion on growth, survival and coralit properties of Porites cylindrical Dana, $J$ of exp mar biol and ecol. 2004;311(2):355-374.

17. Kimberley M. Biorock: Stimulating Coral Growth With Electricity. Treehugger. 2007.

18. Alvarez OM, Mertz PM, Smerbeck RV, et al. The Healing of superficial skin wounds is stimulated by external electrical current. $J$ Invest Dermatol. 1983;81(2):144-148.

19. Yurugi T, Ito S, NumataY, et al. SEM/EDX-Integrated Analysis System, SEM-EDX Series. Horiba Explore the future. 2001;1-5. 